\title{
THE PRELIMINARY INVESTIGATION OF CRIME IN
} FRANCE

\author{
PART III*
}

\section{EDWIN R. KEEDY}

\section{Functions of the Procureur, the Juge D'Instruction and Other Offictals With Regard to Offenses Which Are Consmered Flagrant.}

In theory there is a separation between the powers and functions of the procureur and those of the juge d'instruction. Thus the procureur is not generally empowered to make a judicial investigation (instruction préparatoire) of a suspected offense. This is the special province of the juge, who, however, may ordinarily start such an investigation only when he has been directed to do so by the procureur or when the party who was injured by the offense has constituted himself partie civile. ${ }^{755}$ There is, however, an exception to the general principle in the situations where an offense is committed under circumstances that are considered flagrant. ${ }^{756}$ In such case the powers and duties of both the procureur and the juge d'instruction are enlarged.

In the case of a crime that is considered flagrant the Code imposes on the procureur duties ${ }^{757}$ which are ordinarily performed only by the juge d'instruction. ${ }^{758}$ Thus it is provided that the procureur, after notifying the juge, must proceed (transport) without delay, ${ }^{759}$ accompanied by the greffier of the tribunal, ${ }^{760}$ to the scene of the crime ${ }^{761}$ and there investigate whether the offense has been committed. ${ }^{762}$ Although

* The first two installments of this article, containing footnotes I to 754, appeared in the February and April issues of the Review.

755. See supra p. 692.

756. See discussion of flagrant, supra p. 391. See also L. Caullex, op. cit. supra note 20r, at 297 et seq.

757. Arts. 32-40, 43 and 44. Although Articles 35, 36, 42 and 43 speak both of crime and délit, it is well settled that the application of all the articles mentioned is limited to the case of crimes. 3 GARRAUD, op. cit. supra note I, at 246; GOYET, op. cit. supra note 65, at 245. When the Code d'Instruction Criminelle was promulgated in ISo8, the Code Pénal had not been prepared, and the terms "crime" and "délit" did not have the precise meanings assigned to them in the latter Code. GoYEr, op. cit. supra note 65 , at 245 . Furthermore, Article 32 by its terms covers only flagrants délits which involve an infamous or corporal punishment. According to the Code Pénal such a punishment may be imposed only for a crime. C. P. art. 6 . The projet (I938) for the Code d'Instruction Criminelle uses the term "crime flagrant" in this connection.

758. 3 Garraud, op. cit. supra note $x$, at 249. See supra pp. 692-722.

759. C. I. C. art. 32. The juge need not accompany the procureur. Ibid.

760 . L. Caullet, op. cit. supra note 20I, at 315; 2 LE PoItrevin, op. cit. supra note 74 , at 793 .

76r. C.I. C. art. 32.

762. Ibid. As a practical matter it is frequently difficult for the procureur to determine in advance whether an offense is a crime and, if so, whether it is flagrant. 3 GARRAUD, op. cit. supra note I, at 250 . 
the Code imposes an imperative duty on the procureur, in practice he visits the scene only when he considers that it will be clearly useful, and the Minister of Justice has recommended that this be done only in case of necessity in order to save expense. ${ }^{763}$

When the procureur arrives at the scene he takes statements from any persons who are present or who have information regarding the offense ${ }^{764}$ and also receives statements from such relatives, neighbors or domestic servants as may be presumed to be able to throw light on the affair. ${ }^{765}$ All the statements, which are unsworn, ${ }^{706}$ must be signed by the parties making them or, if they refuse, mention of the fact must be made in the procès-verbal. ${ }^{\text {T67 }}$ After completing his investigation the procureur may order that a person shall not leave the house or depart from the place. ${ }^{768}$ Any person who violates this order may be taken into custody and is also guilty of a contravention, which may be punished by imprisonment not to exceed ten days and a fine of 100 francs. ${ }^{769}$

It is the duty of the procureur to seize any weapons or any other thing employed in, prepared for or produced by the commission of the offense, also anything that may serve to establish the truth. ${ }^{770}$ A procèsverbal ${ }^{771}$ of the seizure must be prepared, which must be signed by the suspect or mention made of his refusal to sign. ${ }^{772}$ In case the offense is of such a character that papers or other articles in the possession of the suspect are likely to have evidentiary value, the procureur should visit the residence of the suspect and make a search for any such articles. ${ }^{773}$ If the procureur finds any articles which may tend to establish either the guilt or innocence of the suspect, the procureur must seize them. ${ }^{774}$ All seized articles must be sealed by the procureur or put in a container which he seals. ${ }^{775}$ All searches and seizures should be made in the presence of the suspect, if he has been arrested; but if he does not wish to attend, then in the presence of a duly authorized representative or of one or two witnesses whom the representative may appoint in his

763. 2 LE PoItTeVIN, op. cit. supra note 74, at 793, citing circulaires.

764. C. I. C. art. 32 .

765. C.I. C. art. 33. The procureur has no right to summon witnesses. GoYeT, op. cit. supra note 65 , at 246 . at 794 .

766. GoYer, op. cit. supra note 65 , at $246 ; 2$ LE PoITTEvin, op. cit. supra note 74 ,

767. C. I. C. art. 33.

768. C. I. C. art. 34 .

769. Ibid.

770. C. I. C. art. 35 .

771. See supra n. 417.

772. C. I. C. art. 35 .

773. C.I. C. art. 36.

774. C. I. C. art. 37, as amended by the Law of Feb. 7, 1933.

775. C.I. C. art. 38, as amended by the Law of Feb. 7, I933. The delivery of any seized document, without the authorization of the suspect or other person entitled to it, to any person not legally qualified to receive it is an offense punishable by a fine of 5000 francs and imprisonment from two months to two years. Any use of the document by such person is punishable to the same extent. Ibid. 
stead. ${ }^{776}$ If the suspect does not name a representative, then any search or seizure should be made in the presence of two members of the family at the dwelling where the search is made. ${ }^{777}$ If the suspect is not in custody, he may be present at any search of his dwelling, but if he does not wish to be present, he may appoint a representative as stated above. ${ }^{778}$ If the suspect is present when papers or articles are seized, they should be shown to him, in order to see if he recognizes them and also to have them initialed by him. ${ }^{779}$ If he refuses, mention of the fact must be made in the procès-verbal. ${ }^{780}$

If the suspect is not present at the search, the procureur issues a mandat d'amener for his arrest. ${ }^{781}$ When taken into custody the suspect is brought before the procureur who is required to interrogate him at once. ${ }^{782}$ In such interrogation the suspect is not entitled to the guarantees accorded him by the Law of December $8, \mathrm{r} 897,{ }^{783}$ notably the right to have the presence of counsel. Except where delay would resuit, the procès-verbal of the procureur must be drawn up in the presence of either the commissaire de police of the commune where the offense occurred or the mayor or deputy mayor or two citizens who reside in the same commune. ${ }^{784}$ Each leaf of the procès-verbal should be signed by the procureur and the witnesses, except where this is impossible or there is a refusal to sign, in which case mention should be made of the fact. ${ }^{785}$ The procureur must without delay transmit to the juge d'instruction all the procès-verbaux and any documents, papers or implements that have been seized.786 These should be examined by the juge, who may continue the investigation, if in his opinion it is incomplete. ${ }^{787}$ If, however, he considers it complete he may dispose of the case, after receiving the recommendations of the procureur, ${ }^{788}$ in the same manner as when he personally makes the investigation. ${ }^{789}$

When the procureur visits the scene of the crime he may take with him, if he considers it necessary, one or two experts qualified to form

776. C. I. C. art. 39, as amended by the Law of Mar. 25, I935.

777. Ibid.

778. Ibid.

779. Ibid.

780. Ibid.

781. C. I. C. art. 40. The fact that a dénonciation has been made against a suspect is not sufficient ground to justify the issuing of a mandat diamener against a person having an established domicile. Ibid.

782. Ibid. The projet (1938) for the Code d'Instrnction Criminelle does not give the procutreur the right to interrogate the suspect.

783. 2 LE PorTTEviN, op. cit. supra note 74, at 797, citing Cass. Mar. 12, 1898. The Law of Dec. 8, I897, is discussed supra pp. 708-7I2.

784. C.I. C. art. 42.

785 . Ibid.

786. C.I. C. art. 45 .

787. C. I. C. art. 60.

788. 2 LE PoItTEvin, op. cit. supra note 74, at 797.

789. See supra pp. 726 and 727. 
an opinion regarding the nature and incidents of the offense. ${ }^{790}$ In case of a violent death or a death whose cause is unknown the procureur will take along two medical practitioners, who will make a report on the caluses of the death and the condition of the corpse. ${ }^{791}$ All the experts are required to take oath before the procureur that they will make their report and give their opinion on their honor and conscience. ${ }^{792}$

The Code expressly provides that all the functions and powers of the procureur in case of a crime that is considered flagrant may be performed by juges de paix, officers of the gendarmerie, commissaires de police and mayors and their deputies, ${ }^{793}$ all of whom are assistants of the procureur in the police judiciaire ${ }^{794}$ These officials should withdraw from the investigation when the procureur arrives, ${ }^{795}$ unless the procureur directs them to continue. ${ }^{796}$ Where a delit is committed in a dwelling and the head of the household requests an investigation, the procureur and his assistants in the police judiciaire should perform the same functions as are prescribed for them in the case of a crime that is considered flagrant. ${ }^{797}$

It is provided by the Law of May $20, I 863,{ }^{798}$ that any suspect who has been arrested for a délit, that is flagrant and is punishable by imprisonment, shall be brought at once before the procureur, who interrogates him. ${ }^{799}$ The provisions of the Law of December 8, I897, do not apply to this interrogatoire. After the interrogatoire the procureur may send the suspect for immediate trial (citation directe) by the Tribunal Cor-

790. C. I. C. art. 43 .

79r. C. I. C. art. 44. If any of the specially qualified persons mentioned in Articles 43 and 44 , after being directed by the procureur to accompany him to the scene of the offense, refuse to do so, they will, unless it is absolutely impossible for them to do so, be guilty of an offense. C. P. art. 475 . Articles 43 and 44 of the C. I. C. are omitted in the projet (I938).

792. C. I. C. art. 44 .

793. C. I. C. arts. 48,49 and 50.

794. C.I. C. arts. 48-54. The Code lists the following members of the palice judiciaire: (1) rural and forest guards, (2) commissaires de police, (3) inspecteurs of the police mobile and of the special police, with at least five years' service, who are designated for this work by the Minister of the Interior and the Minister of Justice, (4) mayors and their deputies, (5) procureurs de la République and their assistants, (6) juges de paix, (7) officers of the gendarmerie, and (8) juges d'instruction. Art. 9. The projet (I938) for the Code omits from the list the procureurs and the juges d'instruction, and adds the following: (a) secretaries of the commissariat de police in the Département of the Seine, and (b) any officials or agents so designated by law. Art. I5. In place of the rural and forest guards are substituted the guards of the Ministry of Waters and Forests and the rural guards of the communes. Ibid. The projet (I938) gives, in case of a crime flagrant, the right to make transports, perquisitions and saisies and to hear witnesses to all officers of the police judiciaire. Arts. 17-20. See discussion of the police judiciaire, supra pp. 407-4II.

795. GOYET, op. cit. supra note 65 , at 246 .

796. C. I. C. art. 5 I.

797. C. I. C. art. 46; 3 GarRaun, op. cit. supra note I, at $248 ; 2$ LE PoITMevin, op. cit. supra note 74 , at 799 .

798. I863 BuLletin des Lors (XI sér.) pt. I, 966. The projet (1938) for the Code d'Instruction Criminelle incorporates the substance of the Law of May 20, I863, except that the procureur is not given the right to interrogate the suspect. Art. 46 .

799. Art. I. 
rectionel. ${ }^{800}$ In such case the procureur places the suspect in detention by a mandat de dépott. ${ }^{801}$ The Law of May 20, 1863, does not apply to offenses by the press, to political offenses nor to any cases where the procedure is prescribed by special laws. ${ }^{802}$ The Law also does not apply to délits committed by recidivists, where the punishment includes banishment, ${ }^{803}$ nor to délits by infants under I8 years of age. ${ }^{804}$

As already stated, ${ }^{805}$ the Code prescribes the situations in which the juge d'instruction may conduct his investigation. The first of these is where he is directed to proceed by the procureur. ${ }^{806}$ This is the ordinary case. The second is where the initiative is taken by the partie civile. ${ }^{807}$ The third situation is where there has been the commission of a crime which is considered flagrant. In such case the juge d'instruction may on his own initiative proceed to an investigation. ${ }^{808}$ He may call upon the procureur to be present, but he need not delay his proceeding because of the procureur's absence. ${ }^{809}$ If the juge arrives on the scene after the procureur has already started an investigation, the latter should withdraw and direct the juge to continue the investigation. ${ }^{810}$ When the juge makes a transport to the scene of the crime, he may immediately interrogate the suspect and make confrontations, if deemed desirable. $^{811}$ In such case the suspect is not entitled to the guarantees of the Law of December 8, 1897.812 However, if the juge after the transport is ended further interrogates the suspect, the provisions of the Law will apply. ${ }^{813}$ Where a délit has been committed in a dwelling house and the head of the household demands an investigation, the juge may exercise the same powers as where there is a crime that is considered flagrant. ${ }^{814}$

The arrest of a suspect ordinarily occurs only upon a mandat d'amener or a mandat d'arrêt. ${ }^{815}$ However, the Code provides for the

800. Ibid.

Sor. Ibid. See discussion of the mandat de dépôt sutpra p. 700.

S02. Art. 7.

803. Law of May 27, I885, art. II, I885 BuLletin des LoIs (XII sér.) pt. I, IIzo. 2097.

804. Law of July 22, I9I2, art. I5, I9I2 BulletiN DES LoIS (nouv. sér.) pt. I,

805. See supra p. 692.

806. C. I. C. 47 .

S07. C. I. C. art. 63 .

808. C.I. C. art. 59. The projet (I938) for the Code d'Instruction Criminelle authorizes the juge dinstruction to start an investigation on his own initiative in the case of either a crime or délit that is considered flagrant. Art. 59.

809. C. I. C. art. 59.

8io. 2 Le Poittevin, op. cit. supra note 74 , at 798.

8II. Ibid.

812. Ibid.

813. Ibid.

8I4. C. I. C. art. 46 ; GoYer, op. cit. supra note 65 , at 284 .

815. Supra pp. 698 and 699. 
arrest without a mandat (arrestation spontanée) in two situations. In the case of a crime that is considered flagrant the suspect should be arrested forthwith by a police officer or by any private person. ${ }^{816}$ In the case of a délit, which is punishable by imprisonment or a more severe penalty and which is considered flagrant, the duty is imposed on the rural and forest guards to arrest the suspect. ${ }^{817}$. The Law of May 20, I863, provides that a person arrested for a flagrant délit, which is punishable by imprisonment, shall be immediately brought before the procureur. ${ }^{818}$ The result of these various provisions is that an arrest should be made by a police officer or private citizen in the case of any crime flagrant or any flagrant délit punishable by imprisonment. ${ }^{819} \mathrm{~A}$ person arrested for a délit should be brought before the procureur, but if arrested for a crime he should be taken to either the procureur or an officer of the police judiciare who is an assistant of the procureur, such as the juge de paix or the commissaire de police who is nearest to the scene of the crime. ${ }^{820}$ The reason for this difference is that where there is a crime flagrant these officers of the police judiciaire have the same right to investigate as the procureur. ${ }^{821}$ It is an offense, punishable by dégradation civique, ${ }^{822}$ for any official to make an illegal arrest. ${ }^{823}$ The victim of the arrest is also given the right to maintain an action for damages against the offending official. ${ }^{824}$

\section{ENQUÊTE OfFICIEUSE}

When the procureur has been informed of an alleged offense by plainte or dénonciation or by the procès-verbal of an officer, he has a wide discretion in determining what procedure to adopt. As it often happens that the information received is not adequate to enable him to decide what course to take, for the purpose of acquiring further information he generally institutes an investigation known as the enquête

816. C. I. C. art. 106. The projet (1938) for the Code d'Instruction Criminelle contains the following provision regarding arrestation spontanée:

"In the case of a crime flagrant, any person is empowered to arrest the perpetrator and to take him before the nearest officer of the police judiciaire or before the gendarmerie.

"He is likewise so empowered in case of a flagrant délit, punishable by imprisonment for a year.

"If the maximum period of imprisonment is less than a year, there may be an arrest only by the officers or agents of the police judiciaire." Art. 36 .

8r7. C.I.C. art. I6. This article does not appear in the projet (I938) for the Code dinstruction Criminelle.

8I8. Art. I.

8I9. 3 Garraud, op. cit. silpra note $\mathrm{x}$, at 240 .

820 . Id. at 242.

821. C. I. C. art. 49; 3 GARRAUd, op. cit. silpra note I, at 242.

822. See supra p. 389.

823. C. P. art. il4; Cunéo, De l'Arrestation et de la Sanction des ArrestatIONS ARbitraires (Thesis Paris, Ig02) in et seq.

824. C. P. art. II7. 
officieuse. ${ }^{325}$ While the procureur may conduct the enquête in person, ${ }^{826}$ he customarily delegates it to his assistants in the police judiciaire, ${ }^{827}$ particularly the commissaires de police and the officers of the gendarmerie in communities having no commissaires de police: ${ }^{828}$ If the investigation is to be made in another arrondissement, the procureur requests the procureur of such arrondissement to secure the information. ${ }^{829}$

There is a wide diversity of opinion among writers regarding the legality of the enquête officieuse. While it is clear that it is not expressly authorized by the Code, ${ }^{830}$ some authorities contend that it falls within the general provision of Article 22 which provides that the procureur "recherche" offenses. 831 On the other hand, it is insisted that the practice is entirely illegal. ${ }^{832}$ A middle ground is taken by some writers who, while admitting that the enquête officieuse is not authorized by the Code, contend that it does not expressly or impliedly forbid the practice. ${ }^{833}$ While the Cour de Cassation has not specifically approved or disapproved the enquête officieuse, it has in some cases employed general language regarding the powers of the procureur, which may be construed as indicating approval. ${ }^{834}$ Circulaires from the Minister of Justice, beginning in I8I7, have encouraged the practice of the enquête officieuse. ${ }^{835}$

In the enquete officeuse the procureur, acting either personally or through his subordinates, employs, if deemed necessary, all the methods

825. 2 GARRAUd, op. cit. supra note $I$, at 627; NADAU, Des ENQUÊTES OfFICIEUSES (19I3) I5; GoYET, op. cit. supra note 65, at 243 ; 2 LE POITTEVIN, op. cit. supra note 74 , at 242 . The enquête officiense is also employed where the procureur decides, as a result of the information contained in the process-verbal, to start a prosecution in the Tribunal Correctionnel by citation directe, but desires to collect further evidence to be presented at the trial. I LE POITTEVIN, op. cit. supra note 74 , at 846 .

826. L. Caullet, op. cit. supra note 20I, at $21 ; 2$ LE PoIrtevin, op. cit. supra note 74 , at 244 . at 65 .

827. L. CAUllet, op. cit. supra note 20I, at $2 \mathrm{I}$; NADAU, op. cit. supra note 825,

828 . 2 MASSABIaU, op. cit. supra note 120 , at 166 ; NADAU, op. cit. silpra note 825, at 66 . Rural communities generally have no commissaires de police.

829. NADAU, op. cit. supra note 825 , at 7 I.

830. 2 GARRAUD, op. cit. supra note I, at 630 ; NADAU, op. cit. supra note 825 , at $252 ; 2$ LE POITTEVIN, op. cit. supra note 74, at 24 I.

83I. L. CAULLET, op. cit. supra note 201, at 22; VERNET, op. cit. supra note 9 , at 29; GOYET, op. cit. supra note 65 , at 243 . The divergence of opinion regarding the legality of the enquête officiense would seem to be due to the different meanings of the word "recherche" contained in Article 22, which outlines the duties of the procureur. In this connection "recherche" may mean either (I) look or search for something, or (2) look into or investigate. LITTRÉ, DICTIONNAIRE DE LA LANGUE FRANÇAISE (I873); Clifton and Grimaux, New French-English Dictionary (r923). Article 22 is omitted from the projet (I938) for the Code d'Instruction Criminelle.

832. 2 Faustrn Hélie, op. cit. supra note 2 , at 24 ; Morrzor-Thibault, op. cit. supra note 20, at 85; SIFNÉos, op. cit. supra note 63 , at I96.

833. 2 GARRAUD, op. cit. supra note I, at 630; NADAU, op. cit. supra note 825 , at 227; PASCAL, op. cit. silpra note 2I6, at 68; 2 LE PoITTEvin, op. cit. supra note 74, at 24I et seq.

834. 2 GARRAUD, op. cit. silpra note $\mathrm{I}$, at 630n.; 2 LE PoITTEVIN, op. cit. supra note 74 , at 242 (citing cases); Sirnḱos, op. cit. supra note 63, at 201.

835.2 GARRAUD, op. cit. supra note I, at 623n.; NADAU, op. cit. supra note 825 , at I6n.; 2 LE PoItTevin, op. cit. supra note 74 , at 243. 
of collecting evidence which the Code provides for the juge d'instruction in conducting his judicial examination. ${ }^{836}$ The scene of the alleged offense is visited for the purposes of observation and inquiry. ${ }^{837}$ Buildings are entered and searched, and objects considered to have evidentiary value are taken, ${ }^{838}$ provided the occupant of the building consents, and this will be ordinarily implied if he does not object. ${ }^{839}$ Doubt has been expressed whether this consent will be implied where the occupant does not know of his right to object. ${ }^{840}$ On the other hand, it is stated that the later decisions of the courts forbid such implication. ${ }^{841}$ Experts are sometimes appointed to make appropriate investigations and to report thereon, but they should not be sworn. ${ }^{842}$

The suspect is frequently interrogated by inferior officers of the police judiciaire, ${ }^{543}$ who informally "invite" 844 him to appear for questioning. If the suspect does not respond to the "invitation", his presence cannot be compelled. ${ }^{845}$ Of course, if the suspect is in custody there is no need for an "invitation". When being questioned, the suspect is not informed of the nature of the charge against him, nor is he permitted to have counsel present, since the Law of December 8, I897, does not apply to this informal interrogation. ${ }^{846}$ If the suspect declines to answer questions, he may not in theory be subjected to compulsion. ${ }^{847}$ The practice, however, is not always in accord with the theory. A study of this situation made by the present writer showed that "third-degree" methods are sometimes employed to extract confessions. ${ }^{848}$

836. NADAU, op. cit. supra note 825 , at 75 .

837. NADAU, op. cit. sipra note 825, at $78 ; 2$ LE PoITtevin, op. cit. supra note 74,

838. 2 GARRAUD, op. cit. supra note $x$, at 627; NADAU, op. cit. supranote 825, at 75 ; VIDAL, OP. cit. supra note 272 , at 920 . 74 , at 245 .

839. 2 GARRAUD, op. cit. supra note I, at 629; 2 LE POITTEVIN, op. cit. supra note

840. Thus it has been stated that there is such implication, although the author strongly asserts that there should not be. Morrzor-THIBAULT, op. cit. supra note 20, at 449 and 450 . To the same effect is NADAU, op. cit. sipra note 825, at roI.

84I. SIFNÉos, op. cit. supra note 63 , at 205 . To the same effect is a recent decision of the Cour de Cassation, discussed in the Revue de ScIence CRIMINeILe (1936) 259.

842. I GARRAUD, op. cit. supra note I, at 603; NADAU, op. cit. silpra note 825, Iro; 2 LE PoItTeviN, op. cit. supra note 74 , at 245 .

843. GoYer, op. cit. supra note 65 , at 243 . This is not regarded "as an official interrogatoire, but simply as informal questioning." BRÉGEAULT ET ALBANEL, op. cit. supra note 546 , at 80 . However, any statements by the suspect are written down in a report which is sent to the procureur. 2 GARRAUD, op. cit. supra note I, at $2 \mathrm{I} 7$.

844. The form of invitation is set forth in 2 AREXY, TRAITE DE POLICE (I925) I095.

845. 2 GARRAUd, $o p$. cit. supra note $\mathrm{I}$, at 628; 2 LE PoITTEvin, $o p$. cit. supra note 74 , at 245 .

846. 3 GarRaUd, op. cit. supra note I, at 432 ; Morizot-THIBAULT, op. cit. supra note 20 , at $4 \mathrm{I} 2$.

847. BRÉGault ET AlBaned, op. cit. supra note 546 , at 79 .

848. Keedy, The Third Degree and Legal Interrogation of Suspects (1937) $85 \mathrm{U}$. of PA. L. Rev. 76I.

"Inferior officials of the police, imbued with the idea that a prosecution can be properly commenced only with a confession, or reduced to seeking by this kind of proof a method for justifying an arrest made with the aid of an informer, which can not be admitted, forget that torture has been abolished for more than a century and seek to 
The hearing of witnesses is an ordinary feature of the enquête officieuse. No formal process may be issued to secure the presence of the witnesses, and their attendance cannot be compelled; they are simply "invited" to appear. ${ }^{849}$ It has been aptly pointed out, however, both with regard to suspects and witnesses, that, being generally unaware of their legal right not to appear, they usually respond to the "invitation". ${ }^{850}$ The witnesses should not be sworn, ${ }^{851}$ but the fact that an oath is administered has no legal effect whatever. ${ }^{852}$

The enquête officieuse is usually justified on the following grounds: (I) that it is necessary, as it is only by such an investigation that the procureur can determine what disposition to make of the case; ${ }^{853}$ (2) that a saving of time and expense results from the fact that, as a result of the investigation, the procureur frequently decides either not to prosecute (classement sans suite) or to refer the case (citation directe) to the Tribunal Correctionnel for prompt trial; ${ }^{854}$ and (3) that if there were no enquête officieuse, it would be necessary to have many more juges d'instruction than at present. ${ }^{855}$

Other grounds for justifying the enquête officieuse are (I) that it gives an opportunity to an innocent suspect to exculpate himself without a formal investigation by the juge d'instruction, ${ }^{856}$ and (2) that a com-

acquire by brutality that which their own gross ignorance of all psychology prevents their seeking by insinuation. Sometimes the suspect is given a slap on the face at each refusal to admit his guilt, at other times he is beaten unmercifully and even knocked to the floor, with some instances of which I am acquainted, and finally, which is the worst, he is sometimes illegally held in custody and tortured by hunger, until the moment when a meal, abundantly washed down by alcohol, following upon a prolonged fast, appears to be the most likely method of loosing his tongue." LOCARD, op. cit. stipra note 275 , at I4. Dr. Locard, in a letter to the writer under date of July 16 , 1936, stated that, while confessions have been formerly obtained by illegal methods, the practice is now extremely rare.

"I know, indeed, that it is sometimes effective for the police judiciaire to interrogate, for fifteen consecutive hours, a person who is without any assistance, without any protection; but torture was also effective. Such methods are unworthy of a free and civilized people." LEPAULLE, op. cit. supra note 324 , at 64 .

"Undoubtedly, maltreatment is not admitted [by the police], but it is frequently seen that the officers boast of having continued their cruel and unfair interrogation for hours, relaying each other, exhausting the suspected man, depriving him of sleep, subjecting him to a moral coercion absolutely not permissible." Io ENCYCLOPÉDIE FRANÇAISE (I935) I0.36.5. I2r.

849. 2 GARRAUD, op. cit. supra note 74, at 627; NADAU, op. cit. supra note 825, at

850. SIFNÉos, op. cit. supra note 63, at 206.

85I. BRfGEAULT ET AlBaNet, op. cit. supra note 546 , at $80 ; 2$ GarRaUd, op. cit. supra note $I$, at 627 ; GoYeT, op. cit. supra note 65 , at 243 ; 2 LE PoITTEviN, op cit. supro note 74 , at 244 .

852. 2 GARRAUD, op. cit. supra note $I$, at 627 (citing decisions); VIDAL, op. cit. supra note 272 , at 921 . The statements of the witnesses need not be signed. BRÉGEAULT ET ALBANEL, op. cit. supra note 546, at 80 .

853. VERNET, op. cit. supra note 9, at 88; CuCHe, op. cit. supra note 217 , at $26 \mathrm{r}$; 2 Le PoItTEvin, op. cit. supra note 74, at 242.

8.54. 2 GARRAUD, op. cit. silpra note I, at 633 ; VIDAL, op. cit. supra note 272 , at $92 \mathrm{I}$; CuCHE, op. cit. sipra note 217 , at 262 .

S55. MoRIzOT-ThIBaULT, op. cit. supra note 20, at 88; 2 GarRaUd, op. cit. supra note $\mathrm{I}$, at 634 ; VERNET, op. cit. supra note 9 , at 89 .

856. Brégeault et AlbaNel, op. cit. supra note 546 , at 79. 
missaire de police or an officer of the gendarmerie, because of his familiarity with local conditions, is more likely to arrive at the truth than the juge d'instruction with his more formal inquiry. ${ }^{857}$

Strong opposition to the enquête officieuse has been expressed on the grounds that it places arbitrary power in the hands of subordinate officials ${ }^{858}$ and that it results in an evasion of the Law of December 8, 1897, which guarantees to the suspect the right to receive notice of the charge against him and to have counsel when undergoing examination. $^{859}$ Some critics, while admitting the propriety and value of the enquete officieuse for the purpose of supplying information to the procureur so that he may decide what action to take in each case, strongly oppose its use in so far as it supplants at a later stage the more impartial investigation by the juge d'instruction. ${ }^{860}$ It has been stated that the juge d'instruction very frequently accepts the results of the enquête officieuse without making any independent investigation. ${ }^{861}$

While the primary purpose of the enquête officieuse is to furnish information to the procureur so as to enable him to decide what disposition to make of the case, the evidence procured by the inquiry is entered in the dossier, which will be considered in case there are any further proceedings. If the case is referred to the juge d'instruction, he will in this way be informed of the persons who may properly be called as witnesses. ${ }^{862}$ If there is a trial in the Tribunal Correctionnel, the information obtained by the enquete officieuse may, after the defendant and his counsel have been given an opportunity to inspect the dossier, be considered as evidence. ${ }^{863}$ If the trial is in the Cour d'Assises, the information may, in the discretion of the President, be presented to the jurors for their consideration. ${ }^{864}$

857. 2 MASSABIAU, op. cit. supra note I20, at I52.

858. 2 FAUSTIN HÉlie, op. cit. supra note 2, at 24 ; StFnÉos, op. cit. supra note 63 , at 224; MORIZOT-T HIBAULT, $o p$. cit. supra note 20, at 530 .

859. "You arrest me in the street and conduct me before the comnissaire. Agitated by this unexpected arrest, I appear without delay before this official even more upset than if I arrived before the juge. However, the commissaire de police questions me, has my statements written down, collects the declarations of witnesses, proceeds to confrontations, and transmits to the parquet all the papers which record these proceedings. He has not been compelled to notify me that I had the right not to answer, and he has not had to submit to the surveillance of my counsel." MORIZOT-THIBAULT, op. cit. supra note 20 , at $4 \mathrm{I} 2$. 9 , at 88 .

860. MORIzot-ThIBAULT, op. cit. supra note 20, at 529; VERNET, op. cit. supra note

86r. M. Emile Kahn, discussing his report on "Organisation de la Police" before the Societé Générale des Prisons et de Législation Criminelle in Revue PÉNITENTIAIRE ET DE Droit PÉNAL (Ig20) r3r. To the same effect is Morizot-Thibault, op. cit. supra note 20 , at 527 .

862. NADAU, op. cit. supra note 825 , at 290 .

863. 2 GARRAUD, op. cit. supra note I, at 632 ; VIDAL, op. cit. supra note 272 , at $92 \mathrm{I}$; CucHe, op. cit. supra note $2 \mathrm{I} 7$, at 262 .

864. C. I. C. arts. 268 and $269 ; 2$ GARRAUd, op. cit. supra note $\mathrm{T}$, at $63 \mathrm{~T}$; NADAU, op. cit. supra note 825 , at 288 ; VIDAL, op. cit. supra note 272 , at 921 . 


\section{Functions of the Préfets}

The projet for the Code d'Instruction Criminelle listed among the officers of the police judiciaire ${ }^{865}$ the préfet de police at Paris and also the préfets ${ }^{866}$ of the départements, but the latter officials were empowered to act only with regard to crimes affecting internally or externally the safety of the State. ${ }^{867}$ As members of the police judiciaire the préfets would have been under the control of the procureur général. 868 At the session of the Conseil d'Etat of August 26, 1808, Napoleon expressed the opinion that the préfets should not be subject to such control and also that their powers should extend to all crimes. ${ }^{869}$ He then directed that an article be drafted to carry out these modifications. ${ }^{870}$ Accordingly, the following draft was prepared as a separate article: "The préfets of the départements and the préfet de police at Paris may conduct personally, or may require the officers of the police judiciaire, each within the authorized scope of his powers, to conduct all the proceedings necessary to establish the commission of crimes, délits and contraventions, and to deliver the offenders to the courts empowered to punish them." This was adopted as Article Io of the Code. ${ }^{871}$ It is important to note that while the draft of the article in the projet in terms limited the powers of the departmental préfets to the investigation of crimes, and Napoleon's recommendations were limited to the same class of offenses, the article as adopted also includes délits and contraventions. Further, although Napoleon emphasized the desirability of the préfet possessing these powers of the police judiciaire in cases where an immediate investigation was necessary and loss of efficiency would occur if the investigation was not made forthwith, ${ }^{872}$ the draft adopted contains no such limitation.

Article ro, as interpreted by the Cour de Cassation, gave the préfets, who are administrative officers, nearly all the powers of investigation possessed by the procureur and the juge d'instruction, 873 including the right of the juge to make searches and seizures in dwellings or

865. The police judiciaire is discussed suprai p. 407.

866. The préfet is the chief administrative officer of a département. CaPITANT, op. cit. supra note 35 , at 383 . See supra p. 392.

867. 25 LOCRÉ, op. cit. supra note 5, at ro2.

868. C. I. C. art. 279.

869. 25 LOCRÉ, op. cit. supra note 5, at 205 and 206. A caveat must be entered as to the precise meaning of crime as used here by Napoleon and as employed in the original draft above referred to. The classification of offenses into crime, délit and contravention did not become settled until the drafting of the Code Pénal in ISro. I Roux, op. cit. supra note 43 , at 93 . "Crime" had previously been defined so as to include all offenses. I De Ferriere, Dictionnaire de Droit et de Pratique (2d ed. I779) 40I. The term was probably so used in the present instance.

870. 25 LOCRE, op. cit. supra note 5 , at 206.

87x. Id. at 68 and 214 .

872. Id. at 205 .

873. 2 GaRRAUd, op. cit. supra note I, at 560; 4 LE PoItTevin, op. cit. supra note 74 , at I5I (citing decisions). 
elsewhere, to seize correspondence in the mails, to issue mandats for the arrest and detention of suspects, to interrogate suspects ${ }^{874}$ and excluding only the right, possessed by the juge d'instruction, to issue official orders at the close of his investigation. ${ }^{875}$ The préfets were even permitted to exercise the power, not possessed by either the juge or the procureur, of acting before a suspected offense was committed by making "preventive" arrests. 870 Although Article ro by its terms permits the préfet to "require" the officers of the police judiciaire to act for him "each within the authorized scope of his powers", it was early decided by the Cour de Cassation that all the powers of the préfet under the article passed to any officer of the police judiciaire directed to act for him. .877

In practice the powers, granted to the préfets by the construction given Article Io, were exercised almost exclusively in Paris 878 and were mostly employed in dealing with types of non-political offenses where promptness and secrecy of action were especially required, such as frauds, counterfeiting, operating gambling houses and traffic in women and drugs. ${ }^{879}$ However, in the case of political offenses, the prefets of the départements as well as the préfet de police in Paris made use from time to time of the extensive powers just discussed. ${ }^{\mathbf{8 0}}$

Article ro, as judicially construed, became increasingly the subject of adverse criticism on both theoretical and practical grounds. Thus it was opposed because it violated the fundamental principle of the separation of powers, stated to be at the basis of the French Constitution, in that it conferred judicial powers on an official of the executive department. ${ }^{881}$ On the practical side the most common objection was

874. Cuche, op. cit. supra note 217, at 253; Brèthe de la Gressaye, La Liberté Individuelle et le Procès Criminel in Les Garanties des Libertés INDIvDUUeles (I933) 69,84 .

875. 2 Garraud, op. cit. supra note I, at $56 \mathrm{~m}$.

876. SrFnéos, op. cit. supra note 63, at 148 (citing decision of the Cour de Cassation) ; UlaAaNN, op. cit. supra note 254 , at $3 \mathbf{I}$.

877. 2 FAUSTIN HÉLIE, op. cit. supra note 2 , at 43 , § I484; SIFNÉos, op. cit. sippra note 63 , at 158 . The préfets were not given the right to delegate their powers to their administrative subordinates, such as the sous-préfets. 2 GARRAUD, op. cit. supra note I, at 574; GOYET, op. cit. supra note 65, at 202 .

878. Guyon, op. cit. supra note 25I, at 254; Ametine, Co QU'Il FaUt Connaître DE LA Police ET DE SEs Mystères (2d ed. I926) I07; GarRaud et Laborde-Lacoste, op. cit. supra note $49 \mathrm{r}$, at 204.

879. MAGNor, op. cit. supra note 43r, at 3n.; Brèthe de la Gressaye, supra note 874, at 85 ; Binet, La Protection de la Liberté Individueliz Contre les Arrestattons ET DÉTENTIONS ARBITRAIRES (I936) 53.

880. 2 GARRAUD, op. cit. supra note I, at 570; BINET, op. cit. supra note 879, at 53 . M. Lépine, préfet at Paris for almost twenty years, minimized the extent to which use was made of Article ro and stated the following: "The préfet acts only in cases of emergency in order to prevent the culprit from escaping justice, or in cases where there is risk that the evidence of the offense will disappear if the opportunity of getting it is permitted to go by." L'́pINE, MES SouvENIRS (I929) 165.

88r. 2 FAUSTIN HÉLIE, op. cit. supra note 2 , at 45 , § I485; 5 Dugurt, TRAITÉ DE DRoIT CoNSTITUTIONNEL (2d ed. I925) 38, 42. "Every party, while in the opposition, has criticized this anomaly which violates the principle of the separation of powers; but by a natural propensity of the French mind, they have all hastened to preserve it when 
that, under the article as it had been construed, the préfets could and did use despotic powers, on which there were no legal restraints such as the law placed upon the procureur and the juge d'instruction. $^{882}$ As a result, the guarantees of personal liberty ${ }^{883}$ and of the inviolability of the dwelling, ${ }^{884}$ secured as against the judicial officers of the government after long and strenuous struggles, could be and were violated by the executive arm. ${ }^{885}$ Again it has been said that the préfets used Article Io as an improper but effective weapon against the political enemies of the party or officials in power. ${ }^{886}$ Still another basis of opposition to the article was found in its debilitating effect upon the prosecuting department, chiefly the parquet of the Seine in Paris, where the interference by the préfet de police was strongly felt. The reports of offenses prepared by commissaires de police, the subordinates of the procureur in the police judiciaire, were caused by the

they succeed to governmental power." MORIzoT-THIBaULT, op. cit. supra note 20 , at 38. "There was a flagrant violation of the principle of the separation of powers, so often invoked in France since Montesquieu and which the Constituent Assembly had intended to prevail under all circumstances." Leloir, annotation to the Law of Feb. 7, r933, in DALLOZ, RECUEIL PérTódigue, I933 IV. 66.

882. See SIFnÉos, op. cit. supra note 63, at I59.

883. For example, when interrogated by order of the préfet, a suspect had no right to have counsel or any third person present. The Law of Dec. 8, I897 was not applicable. 2 GARRAUD, op. cit. supra note I, at 57I; GUYON, op. cit. supra note $25 \mathrm{I}$, at 254 ; MAGNoL, op. cit. supra note 43I, at 5. The contrary view is expressed in 2 Roux, $o p$. cit. supra note 43 , at 33 .

884. "The power of making arrests, of making searches and seizures in private dwellings, of seizing, even in the mail, the correspondence of individuals-all this was excessive." Leloir, loc. cit. supra note 88r. "It is astonishing to find this article still in our codes. Its abrogation has always been one of the dogmas of the republican program and all parties ought to agree to its immediate repeal. It constitutes the absolute negation of the principle of the separation of powers; it can be in practice the most despotic and dangerous instrument. It destroys all the safeguards instituted in the penal laws; it permits the administrative authority to arrest and maintain in prison for several days any individual who is suspected by the Government, as well as to make searches and seizures and even interrogations." Report of M. Busson-Billault, Senator, in Journal OfFicier, Sénar, Doc. PARL. (I92I) annexe no. 256, p. 586.

885. 2 FAUSTIN HELIE, op. cit. supra note 2, at 44 , § I485; VIDAL, op. cit. silpra note 272 , at $89 \mathrm{I}$. "These excessive attributes of the préfets are disquieting for individual liberty, the inviolability of the dwelling and the privacy of correspondence. In political matters the action of the preffets supplants that of the judicial department for making arrests and seizures of doubtful legality which a juge d'instruction would decline to order." LABORDE, op. cit. supra note I32, at 620 . "Under the second Empire numerous arbitrary acts committed by virtue of this article have been cited; it is only just to say that ones so grave are not committed today, but there is always the latent peril, especially since an individual, placed under a mandat de dépôt by the préfet de police, has no legal means at his disposal to force his being brought to trial. It has been said, in speaking of this article, that the lettre de cachet still exists in France, since the préfet de police can with impunity have an individual imprisoned any time he pleases. The only difference between the older incarceration by lettre de cachet and incarceration under Article Io is that the latter must be buttressed by a legally punishable infraction. But this charge need not be bona fide, so that there is always the possibility of inventing one." GuYoN, op. cit. supra note 25I, at 255 . To the same effect are HALEVY, LA DÉCAdence dE LA LIBERTÉ (I93I) I58; UlaranN, op. cit. supra note 254, at 3 r.

886. Morizot-Thibault, op. cit. supra note 20, at 38 ; GuYon, op. cit. supra note 25I, at 256; Brèthe de la Gressaye, sitpra note 874 , at 84 . The préfets ought not to use their exceptional powers in political cases. LEPINE, op. cit. sipra note 880, at I66. 
préfet de police to be sent to him rather than to the procureur. At the préfecture the reports were sorted and those offenses which the préfet desired to have prosecuted were referred to the procureur with instructions to that effect. The reports in the other cases would be "filed", thus accomplishing an informal classement sans suite ${ }^{887}$ without reference to the procureur. ${ }^{888}$ Although the writers generally denied that the prefetes had any right to continue their own investigation and to exercise coercive measures, such as arrest and detention, after the procureur or the juge d'instruction had taken charge of the particular case, ${ }^{889}$ in practice the préfets did not refrain from continuing their activities concurrently with those of these officials, ${ }^{890}$ evidently with the approval of the courts. ${ }^{891}$

Although Article Io and its construction were much criticized, at the same time support for the extraordinary powers of the préfets was not lacking. The préfets themselves on numerous occasions urged the necessity of preserving these powers, ${ }^{892}$ and this view was supported by some writers and public officials. ${ }^{893}$ The principal reason advanced for retaining the powers of the préfets, particularly the préfet de police of Paris, was the fact that these officials acted more promptly and efficiently than the procureur and the juge d'instruction. ${ }^{894}$

887. See discussion of classement sans suite, supra p. $42 \mathrm{r}$.

888. Morizot-Thibault, op. cit. supra note 20 , at $39 ; 2$. Garraud, op. cit. supra note $I$, at 569 ; LABORDE, $o p$. cit. supra note 132 , at 620 . The repeal of Article to has been urged on the ground that the peculiar conditions existing at the time the Code was drafted, when after the Revolution the Government was new and the judicial authority was weak and a veritable horde of criminals was overrunning the country, no longer justify such a measure. 2 FAUSTIN HíLIE, op. cit. sippra note 2 , at $44, \$ I 485$; Morizot-Thibault, op. cit. sipra note 20 , at 38 .

889. 2 GARRAUd, op. cit. supra note I, at 573, 574; LABORDE, op. cit. supra note I32, at 622; GoYET, op. cit. supra note 65 , at $202 ; 4$ LE POITTEVIN, op. cit. silpra note 74 , at I5I (citing a circulaire of the Minister of Justice, dated March 26, I854).

89o. A circulaire of the Minister of the Interior, dated Aug. 4, Ig06, urged the préfets to refrain from such a practice without, however, stating it to be illegal. CuCHE, op. cit. supra note 217 , at 253 .

89I. GarRaud et LaboRde-Lacoste, op. cit. supra note 49I, at 203, 204.

892. LÉPINE, op. cit. supra note 880, at I66; GuYoN, op. cit. supra note $25 \mathrm{I}$, at 254 ; BINET, op. cit. supra note 879 , at 52 .

893. CUCHE, op. cit. supra note 2r7, at 252; HaLEvy, op. cit. supra note 885 , at I92; Brèthe de la Gressaye, supra note 874, at Iog. "There is the law, but there is also the duty of governing - the necessity of preserving the public order. These are two ideas which the Republic must reconcile." M. David, Senator, in Journal OFFICIEr. SÉnAT, DÉb. PARL. (June 22, Ig22) 903.

894. 2 GARRAUd, op. cit. supra note I, at 569 ; LESTELLE, op. cit. supra note 24 , at 39. "In order to be able to combat effectively the numerous criminals in Paris, it is of importance that the supreme authority possess effective weapons. The police often has need of being prompt-it cannot always be encumbered by judicial formalities. Thanks to Article Io the préfet de police can order searches which are executed at once. This prompt execution is often the condition necessary to success. It is by virtue of Article Io that raids in suspected quarters are made which often bring about the discovery of criminals." GuxoN, op. cit. supra note $25 \mathrm{I}$, at 254 . To the same effect is LESTELLE, op. cit. supra note 24 , at 39 . 
Repeated efforts were made in Parliament for the repeal of Article Io. ${ }^{\$ 95}$ In I879 a commission appointed to revise the Code d'Instruction Criminelle recommended the repeal of the article, ${ }^{896}$ but the Government modified the projet by recommending an amendment of the article so as to limit its application to the préfet de police in Paris. ${ }^{897}$ The Senate in 1882 voted favorably on this amendment with the further limitation that it would apply only in the case of a flagrant delit. ${ }^{898}$ In 1884 the Chamber of Deputies voted for the repeal of the article. ${ }^{899}$ The Senate voted to repeal the article in 1909,900 and the Chamber of Deputies voted for its repeal in I918.901 In 1922 the Minister of Justice, M. Barthou, stated in the Senate that the Government was ready to accept the repeal of Article 1o, adding, "If the present Government thinks that Article Io of the Code d'Instruction Criminelle may be abrogated, it is because it has the profound and carefully weighed conviction that there will remain for it in the Code d'Instruction Criminelle the means of coping with the exigencies which have been pointed out. . . . Certainly it would be strange for France to be the only nation of the civilized world which had to have, for the protection of the Government, a provision as extraordinary as Article IO". ${ }^{902}$ The Senate accordingly voted for the repeal of the article, ${ }^{903}$ but there was no action by the Chamber of Deputies.

In 1933 the efforts of over a half century culminated in the repeal of Article 10. ${ }^{904}$ It was not long, however, before demands for its restoration to the Code were heard, based mainly on the same grounds as had been formerly advanced against its repeal, ${ }^{905}$ to which added weight was given by evidence that the Government had been seriously hindered in dealing with the fatal riots of Feb. 6. I934, because the

895. "It seems that the political parties are divided between two contrary sentiments-they would like to suppress it [Article Io] for fear their adversaries will use it against them, but they would also like to preserve it, in order to be able, when opportunity arrives, to use it against their opponents." VERNET, op. cit. supra note 9, at 26. To the same effect is LESTELLE, op. cit. sipra note 24 , at 30 .

896. Gabolde, Commentaire de la LoI du 7 FÉvrier i933 sur les Garanties de LA LIBERTE INDIVIDUELLE (I933) I8.

897. Ibid.

898. Ibid.

899. Journat Officiel, Chanibre, Déb. Pard. (Nov. 4, i884) 2205.

900. Journal Officter, Senat, Déb. Pard. (Feb. 9, I909) 96.

90I. Journal Officter, Chambre, DÉb. Pard. (July I6, rgig) 3515.

902. Journal Officiel, Sénat, DÉb. Pard. (June 22, I922) 900.

903. Journal Offictel, Sénat, Déb. Pard. (June 23, ig22) 898.

904. Law of Feb. 7, I933, art. I, Journal OFFICIEL (Feb. 9, I933) I354. This law also amended Article I20 of the Code Pénal so that any warden of a prison or place of detention of any kind who received a prisoner without a warrant or judgment, except in cases of extradition or expulsion from the country, or who unlawfully detained such a prisoner would be guilty of an offense punishable by imprisonment of six months to two years and a fine of 16 to 200 francs. GABOLDE, op. cit. supra note 896, at 20.

905. LESTELLE, op. cit. supra note 24 , at 87 et seq. 
préfet de police lacked the powers previously conferred by Article Io. ${ }^{008}$ It was emphatically pointed out that serious delay in the investigation of offenses resulted from the repeal of the article, ${ }^{907}$ and little objection was made to proposals for its reenactment. ${ }^{908}$ The Government by the Minister of Justice and the Minister of the Interior introduced in the Senate on May I5, I934 the following bill:

"The préfets of the départements and the préfet de police in Paris may, if there is an urgent ${ }^{909}$ situation, conduct personally, or may require the officers of the police judiciaire, each within the authorized scope of his powers, to conduct all the proceedings necessary to establish the commission of crimes and délits against the internal or external safety of the State, ${ }^{910}$ and to deliver the offenders to the courts empowered to punish them.

"Any préfet who shall have exercised the powers conferred on him by the preceding paragraph must inform the procureur and transmit the evidence within twenty-four hours to the procureur who will then take charge of the investigation. ${ }^{911}$

906. Letter of Mar. 6, I935, from Ligue Française pour la Défense des Droits de l'Homme et du Citoyen to members of the Chamber of Deputies. The writer obtained a copy of this letter from the Ligue.

907. "At the present time, with the repeal of Article Io, it is impossible for the police to proceed to a sudden and unexpected seizure, for example, in cases of espionage. The parquet must first be notified, which then causes the opening of a formal investigation by a juge d'instruction preparatory to which there must be the assembling of certain papers, their examination, their sending back and forth; then certain orders must be given and certain inspections made of the scenes connected with the offense. All this takes time, to such an extent that the juge almost always arrives too late." M. BoivinChampeaux, Senator, speaking in the Senate debate of Dec. 21, I934. JourNAI OFFICIEL, SÉNAT, DÉB. PARL. (I934) I48T. "The government thought that the suppression of the judicial powers of the prefets had frequently rendered difficult the discovery of certain offenses, which could have been discovered only by sudden measures, such as an unexpected visit to the suspected places. Extraordinary and urgent circumstances may in fact require immediate action for the safeguarding of the public order and the very safety of the State, notably at the frontiers or in a center of agitation. Undoubtedly a juge d'instruction can be rapidly named but that necessitates an order of the procureur, which may be given only upon strong presumption of the commission of a crime or délit. The préfets are better informed than the magistrats, because they have better police officers than the latter; they are also by reason of this fact better equipped to act and to do so more quickly-their action can be instantaneous." MAGNOL, op. cit. supra note $43 \mathrm{x}$, at $2 \mathrm{n}$.

908. Brunschvicg, La Liberté Individuelle au Sénat, 35 Les CaAIrers des DroIts DE L'HOMME (1935) I08, I09; ULMANN, op. cit. supra note 254, at 3 In. "The reestablishment of Article ro, too evidently dictated by considerations of political opportunism, can be approved only provisionally and to the extent that circumstances justify it." LESTELLE, op. cit. supra note 24 , at $\mathrm{I} 86$.

909. The préfets will be the sole judges as to whether there is an urgency. LESTELLE, op. cit. supra note 24 , at II2.

910. "Offenses against the external safety of the State are taking up arms by a Frenchman against France, maintaining communications with foreign powers in order to facilitate war against France, delivering state secrets or military plans to agents of a foreign government, hiding enemy spies and all infractions of law of the kind which chiefly occur during war. Offenses against the internal safety of the State are attempts against the form of the government, conspiracy, inciting to civil war, levying armed troops without the order or permission of the lawful authority, destroying public buildings and organizing armed bands." LESTELLE, op. cit. supra note 24 , at II2.

9II. The powers of the préfets are now clearly "subsidiary" to those of the juge d'instruction and the procureur. MAGNOL, op. cit. supra note 43I, at 5. 
"Any officer of the police judiciaire authorized by the préfet acting under the above provisions and any public official notified of a seizure under the same provisions must without delay notify the procureur de la République." 912

It will be noted that the new article is almost identical with the article in the original projet of I804 which Napoleon caused to be expanded.913 It is a curious fact that the article, as amended, did not empower the préfets to act in the large class of cases, such as frauds and traffic in women and drugs, regarding which it was declared, both before and after I933, that the prompt and energetic action of the préfets was necessary.914 The projet (I938) for a new Code d'Instruction Criminelle, however, contains an article which extends the power of the préfets so as to include the following offenses: possession and sale of drugs, operation of gambling houses and the white slave traffic. ${ }^{915}$

A decree of July I, I939, provides that in case of a national emergency, including war, the préfets shall exercise the extensive powers, which have been discussed, with regard to crimes, délits and contraventions of every kind and shall have three days, instead of twenty-four hours, in which to transmit the case, with a report of the evidence, to the procureur. ${ }^{916}$ Under this decree the préfets have broader powers than they ever had before.

\section{Chambre D'Accusation}

The chambre d'accusation ${ }^{917}$ is a section of the Cour d'Appel. ${ }^{918}$ This chambre is composed of three judges, including a President, selected from the other chambres of the Cour d'Appel. ${ }^{919}$ These judges act as members of the chambre d'accusation in addition to their other duties. A member of the ministère public ${ }^{920}$ and the greffier must be present at each session of the chambre, ${ }^{921}$ which meets either on the call of the procureur général or without such call at least once a week.922

The chambre d'accusation has three functions. When a juge d'instruction, at the end of his investigation, is of the opinion that a

912. Law of Mar. 25, I935, art. 6, Journal OfFrciel (Mar. 26, I935) 3428.

913. See supra p. 925.

9I4. See supra p. 926 .

9r5. Art. I4.

9I6. Art. I, JouRnal OfFiciel (July 2, I939) 8345 .

917. The full title is chambre des mises en accusation. This chambre is the successor to the jury of accusation, similar to the English grand jury, instituted by the Law of Sept. I6-22, I79r. 3 GARRAUD, op. cit supra note $I$, at 33I. The history of this chambre is set forth at length in FÉQUANT, DE LA CHAMBRE DES MISES EN ACcUSATron (Thesis Paris, IgOI) 9 et seq.

9I8. See supra pp. 395 et seq.

919. I LE PoITTEvin, op. cit. supra note 74, at 7I8. In Paris, however, the chambre d'accusation has a permanent and independent status. Id. at $7 \mathrm{x} 9$.

920. The procureur général attached to the Cour d'Appel or one of his assistants.

92I. 3 GARRAUD, op. cit. supra note I, at 334 .

922. C.I. C. art. 218 , as amended by the Law of July $17,1856$. 
crime has been committed and that there is sufficient evidence to justify further proceedings against the suspect, he refers the case ${ }^{\mathbf{9 2 3}}$ to the chambre, which determines whether the case shall be brought to trial and, if so, in what court, depending upon whether it agrees with the findings of the juge d'instruction. Another function of the chambre is the hearing of appeals from the ordonnances of the juge d'instruction. ${ }^{224}$ It also exercises a general supervision over all the proceedings of the preliminary investigation ${ }^{925}$ and in this capacity may start a new investigation ${ }^{926}$ or may take over an investigation already started by a juge d'instruction. ${ }^{927}$

When a case has been referred to the chambre by the juge d'instruction, ${ }^{92 s}$ the first duty of the chambre is to determine if it is competent to proceed. For example, it will not be competent if the case falls within the jurisdiction of a special court, such as a court-martial, or if the case is not within the territorial jurisdiction of this Cour d'Appel. ${ }^{\text {229 }}$ The chambre then determines whether or not the investigation made by the juge d'instruction is complete. If not, it orders a supplemental investigation. ${ }^{930}$ The chambre further decides whether a prosecution is barred for some reason, such as res judicata, prescription or amnesty. ${ }^{931}$

The proceedings of the chambre are secret.932 Neither the suspect nor the partie civile is permitted to be present at any time, but they may present written arguments to the chambre. ${ }^{933}$ The procureur général or one of his assistants may present arguments, generally written, on behalf of the prosecution, but should retire before the juges begin to deliberate, ${ }^{934}$ as the Code provides that the juges shall not consult anyone during their deliberations. ${ }^{935}$

The chambre does not hear any witnesses, but bases its deliberations and findings entirely upon the written report of the case (dossier)

923. See supra p. 727.

924. C. I. C. art. I35.

925. 3 GARRAUD, op. cit. supra note I, at 347.

926. The chambre may appoint either one of its members or a juge d'instruction to conduct the investigation. C. I. C. arts. 235-240.

927. 3 GARRAUD, op. cit. supra note $I$, at 347 .

928. Notice must be given to the suspect and the partie civile twenty-four hours before the case is referred to the chambre. C. I. C. art. II6, as amended by the Law of Mar. 25, I935.

929. FEQUANT, op. cit. supra note 917 , at 70 ; I Le PoITTEviN, op. cit. supra note 74 , at $72 \mathrm{I}$. 349 .

930. FÉQuANT, op. cit. supra note 9I7, at 94; 3 GARRAUd, op. cit. supra note $\mathrm{I}$, at

93I. FÉQUANT, op. cit. supra note 9I7, at 72.

932. 3 GARRAUD, op. cit. supra note $\mathrm{I}$, at 335 .

933. C.I. C. art. 217. In order to assist the suspect and the partie civile in the preparation of their arguments they are permitted to inspect the record of the case. FEQUANT, op. cit. supra note 9I7, at 149 . 342.

934. FÉQUANT, op. cit. supra note 9T7, at I47; 3 GARRAUD, op. cit. supra note $I$, at

935. C. I. C. art. 225 . 
and the arguments made by the procureur général or his assistant and those submitted by the suspect and the partie civile.936 The greffier reads the dossier and the written arguments to the juges, ${ }^{937}$ whose function is to review the findings made by the juge d'instruction at the end of his investigation..$^{938}$

A decision of the chambre d'accusation is known as an arrêt and is determined by a vote of the majority. ${ }^{939}$ If the juges determine either that an offense was not committed or that the evidence is not sufficient to warrant the trial of the suspect, they will order that he be immediately set at liberty. ${ }^{940}$ In such case the suspect may not be again proceeded against upon the same charge unless additional incriminatory evidence is later discovered. ${ }^{041}$ If the juges conclude that there is suffcient evidence of a contravention, the suspect will be sent to trial by the Tribunal de Simple Police; if sufficient evidence of a délit, by the Tribunal Correctionel. ${ }^{942}$ In case they conclude that a crime has been committed by the suspect, they will order that he be brought to trial before the Cour d'Assises, ${ }^{943}$ which is competent to try only such persons as are sent to it by the chambre d'accusation. ${ }^{944}$

Following the decision of the chambre to send the suspect before the Cour d'Assises, the procureur général is required to prepare the formal accusation, known as the acte d'accusation, which must specify the following: (I) the offense charged, (2) the criminal act with a statement of all the circumstances, which may aggravate or reduce the punishment and (3) the name and description of the accused. ${ }^{945}$

Appeals to the chambre d'accusation from the ordonnances of the juge d'instruction may be taken by the procureur, the suspect and the partie civile. The procureur may appeal from any ordonnance, while the suspect may appeal only from an ordonnance fixing bail. ${ }^{946}$ The partie civile is given the right to appeal from ordonnances setting the suspect at liberty or releasing him on bail and from any other ordonnances unfavorable to his civil claim. ${ }^{947}$

936. 3 GarRaUd, op. cit. supra note $r$, at 336 .

937. C. I. C. art. 222.

938. 3 GARRAUD, op. cit. suprat note $\mathrm{r}$, at 336 .

939. Id. at 343 .

940. C. I. C. art. 229, as amended by the Law of July I7, I856.

94I. C. I. C. art. 246.

942. C. I. C. art. 230 , as amended by the Law of July I7, I856.

943. C. I. C. art. 23I, as amended by the Law of July 17 , I8 56 .

944. 3 GARRAUD, op. cit. supra note I, at 346 .

945. C. I. C. art. 24r.

946. C. I. C. art. I35.

947. Ibid. 